\title{
EVIDENCE OF AN "ENERGY-MANAGEMENT GAP” IN U.S. MANUFACTURING: SPILLOVERS FROM FIRM MANAGEMENT PRACTICES TO ENERGY EFFICIENCY ${ }^{1}$
}

\author{
by \\ Gale Boyd* \\ Department of Economics, Duke University \\ Mark Curtis $\dagger$ \\ Department of Economics, Georgia State University
}

CES 13-25 April, 2013

The research program of the Center for Economic Studies (CES) produces a wide range of economic analyses to improve the statistical programs of the U.S. Census Bureau. Many of these analyses take the form of CES research papers. The papers have not undergone the review accorded Census Bureau publications and no endorsement should be inferred. Any opinions and conclusions expressed herein are those of the author(s) and do not necessarily represent the views of the U.S. Census Bureau. All results have been reviewed to ensure that no confidential information is disclosed. Republication in whole or part must be cleared with the authors.

To obtain information about the series, see www.census.gov/ces or contact Fariha Kamal, Editor, Discussion Papers, U.S. Census Bureau, Center for Economic Studies 2K132B, 4600 Silver Hill Road, Washington, DC 20233, CES.Papers.List@ census.gov. 


\begin{abstract}
In this paper we merge a well-cited survey of firm management practices into confidential U.S. Census microdata to examine whether generic, i.e. non-energy specific, firm management practices, "spillover" to enhance energy efficiency in the United States. We find the relationship in U.S. plants to be more nuanced than past research on UK plants has suggested. Most management techniques have beneficial spillovers to energy efficiency, but an emphasis on generic targets, conditional on other management practices, results in spillovers that increase energy intensity. Our specification controls for industry specific effects at a detailed 6-digit NAICS level and shows that this result is stronger for firms in energy intensive industries. We interpret the empirical result that generic management practices do not necessarily spillover to improved energy performance as evidence of an "energy management gap.”
\end{abstract}

${ }_{1}$ We thank participants in the Energy Star Industry Focus, 2012 AERE Summer Meetings, 2012 Atlanta Census Research Data Center Conference, Triangle Resource and Environmental Economics Seminar Series, and HERU Working Group at Georgia State for helpful comments and suggestions. Any opinions or views expressed are those of the authors and do not necessarily represent those of the U.S. Census Bureau. All results have been reviewed to ensure that no confidential information is disclosed.

*Department of Economics, Duke University (email: gale.boyd@duke.edu)

†Department of Economics, Georgia State University (email: ecurtis3@gsu.edu) 


\section{Introduction}

The notion that a "well-managed" company does all things equally well, begs the question of whether management practices need to be targeted to specific results/goals or will simply "spill over" into good performance in all aspects of the firm. This paper explores this issue by looking for evidence of an "energy management gap" in otherwise well managed companies. If there are no positive spillovers, i.e. no improvements in energy performance resulting from good management, then we interpret this as evidence of this different type of "energy gap." In particular, we examine whether "generic" management practices, i.e. those that are not specifically targeted to energy, which have been measured in a carefully constructed survey, result in improved energy performance. We use non-public plant level data to conduct the study, controlling for differences in plant energy use at a detailed, 6-digit NAICS industry level and also for differences in industry average energy intensity. The former is done to avoid mistaking differences in the energy requirements to produce various products as differences in "energy efficiency." The latter is done to see if the scale of the "energy spend" is more likely to put energy on the radar of management. We find beneficial spillovers for some types of management practices, but not all. Energy use by firms in energy intensive industries responds more to management practices. However, some management practices actually increase relative energy intensity instead of lowering it. We interpret this result as evidence of an "energy management gap."

Energy economists have devoted substantial resources to understanding both the extent of and the reasons for the so called "Energy Efficiency Gap." ${ }^{1}$ That this topic is of great interest

\footnotetext{
${ }^{1}$ See DeCanio (1993), Jaffe and Stavins (1994) DeCanio and Watkins (1998), Boyd et al. (2011), Alcott and Greenstone (2012).
} 
should come as no surprise given that improvements in energy efficiency could potentially result not only in increased levels of firm profits but also in decreased levels of the harmful pollutants associated with burning fossil fuels. One traditional explanation for why firms vary in their energy efficiency is that unobserved differences in management quality lead some firms to adopt more efficient production techniques and to improve the monitoring of their inputs. Well run firms will be quick to spot wasteful energy use and poorly run firms may be more likely to suffer from incomplete information and principal-agent problems. While economists have puzzled over the empirical observations and developed new approaches to measure efficiency, business schools and consultancies have long recognized that lean production techniques, setting targets and providing incentives to workers can lead to increased productivity and more efficient use of inputs generally, and energy specifically, e.g. McKinsey (2009).

The environmental policy implication of lower energy use has led to the development of voluntary government programs for energy efficiency, particularly in the absence of or supplement to other types of climate policy. These programs arose in the early 1990's (Storey, et al. 1997) and expanded in the US with the introduction of EPA Energy Star for Industry (Boyd et al. 2008) and various DOE programs like Climate Leaders, Save Energy Now, and Superior Energy Performance (SEP). These programs may require company or industry level commitments to specific energy reduction targets, or "energy management" generally. For example, a company joining Energy Star agrees to

- Measure, track, and benchmark energy performance

- Develop and implement a plan to improve energy performance, adopting the ENERGY STAR strategy 
- Educate your staff and the public about your partnership and achievements with ENERGY STAR ${ }^{2}$

More recently, the International Standards Organization (ISO) has established requirements for "establishing, implementing, maintaining and improving an energy management system, whose purpose is to enable an organization to follow a systematic approach in achieving continual improvement of energy performance, including energy efficiency, energy use and consumption" as ISO $50001^{3}$ which largely formalized the first two elements of the Energy Star partner agreement.

The US based voluntary energy programs typically involve some type of government recognition for "good" performance. Energy Star provides recognition for plants that reduce energy (ES Challenge), that are in the upper quartile of performance (ES Certification), and a corporate level award to overall achievements (ES Partner of the Year). The recently established DOE/SEP recognition program uses ISO 50001 as its core requirement and requires various levels of performance to achieve formal recognition ${ }^{4}$. International programs may have more binding agreements in exchange for a variety of other incentives such as audits and assessments, financial assistance and incentives, exemption from regulation and taxes, in addition to government and public recognition (Price, L., E. Worrell, et al. (2003). While researchers have directly examined the impacts of these programs, the difficulties in quantifying a firm's management practices have prevented them from studying the exact mechanisms that lead to improved energy use. ${ }^{5}$ In recent years a small but growing economics literature has emerged

\footnotetext{
${ }^{2}$ http://www.energystar.gov/index.cfm?c=business.bus_commit

${ }^{3} \mathrm{http} / / / \mathrm{www}$.iso.org/iso/iso_catalogue/catalogue_tc/catalogue_detail.htm?csnumber $=51297$

${ }^{4}$ See http://www1.eere.energy.gov/manufacturing/tech deployment/sep.html for more details

${ }^{5}$ It should be noted that all these voluntary programs are focused specifically on energy management, not management practices generally.
} 
which seeks to overcome the dearth of quantifiable measures of firm management practices (Bloom and Van Reenen 2007; Martin et al. 2012). Innovative survey techniques have been used to elicit reliable answers from plant managers on whether they have adopted effective monitoring, operations, targets and incentives practices. These data have been matched to firm level production data to examine total factor productivity for firms around the world (Bloom and Van Reenen 2007; Bloom et al. 2012; Lazear and Oyer 2012; Martin et al. 2012). More recently, two papers have examined the relationship between management practices and energy efficiency for a subset of firms in the UK (Bloom et al. 2010; Martin et al. 2012). Given the lack of easily accessible establishment level data in the United States, there has heretofore been no studies to examine the relationship between management practices and energy efficiency for firms in the United States. ${ }^{6}$ In order to fill this hole in the literature we link management survey data collected by Bloom and Van Reenen (BVR) with detailed establishment level data found in the Census of Manufactures (CM). Performing this merge allows us to observe detailed plant-level output and energy expenditure data found in the CM to determine if these generic management practices are a predictor of energy efficiency for U.S. manufacturing plants.

Previous research on UK firms has shown an unambiguous positive relationship between management practices and energy efficiency. Using data on U.S. manufacturing establishments we find this relationship to be more complex. Not all forms of "good" management practices are associated with improvements in energy efficiency. Effective monitoring, incentive structures and lean manufacturing operations are shown to be related with a reduction in energy use while the implementation of generic management targets

\footnotetext{
${ }^{6}$ The research on management and TFP for U.S. firms is also limited. Bloom and Van Reenen (2007) collect management score data for a sample of all U.S. but the TFP results rely on Compustat data which contains only publicly listed firms.
} 
(conditional on other practices) are found to increase energy consumption. Furthermore, the relationship between management practices and energy efficiency is more prominent within energy intensive industries, i.e. those that require high levels of energy in their production process. Management practices are shown to have lower association with energy efficiency in industries for which energy is a small component of their overall costs.

As with the rest of the literature on the topic, the observed relationships between management practices and the outcome variables of interest do not necessarily imply causality. The empirical analysis attempts to control for other factors that may be driving differences in energy efficiency, but there remains the possibility that omitted variables could be correlated with both management practices and energy use. Perhaps firms that are more willing to hire management consultants are also more likely to adapt energy saving techniques for reasons unrelated to their management practices ${ }^{7}$. However, there are a variety of mechanisms through which management practices may strongly impact in energy efficiency. First, effective communication between production workers and plant managers may lead upper management to more quickly be aware of wasted resources at the floor level. Workers whose pay is tied with production efficiency may be more likely to notice and address these issues and overcome potential principal-agent problems within the firm. The implementation of "lean" manufacturing techniques will also reduce energy waste. These techniques allow for the computerized monitoring of every step in the production process and are meant to closely track use of resources. These techniques also permit the effective

\footnotetext{
${ }^{7}$ Current research (Bloom et al 2012) is attempting to overcome causation issues by collecting panel data on management practices. Ongoing research in India randomly assigns certain plants to receive intensive management consulting.
} 
monitoring of capital and inputs thus providing plant managers the information they need to identify and address bottle necks and inefficiencies in production.

We believe that this paper makes a number of important contributions to the emerging literature on firm characteristics and energy efficiency. As the first paper to link a large scale survey of firm management practices to the confidential plant level data found in the Census of Manufactures, we are able to explore previously unexamined relationships between management and energy use. Contrary to previous research we discover that not all management practices are associated with energy efficiency. High management scores for the operations, monitoring and incentives categories have a beneficial impact on energy use, while an emphasis on targets, conditional on other management components, tend to make firms less energy efficient. We also show that management practices are more predictive of energy efficiency within industries where energy is a higher portion of production costs. Within these energy intensive industries management practices appear to be a sizable source of energy savings. For firms in energy intensive industries, improving their operations, monitoring and incentives management score from the $25^{\text {th }}$ to $75^{\text {th }}$ percentile is associated with a reduction in energy consumption of around $15 \% .^{8}$ Given that the manufacturing sector consumes $25 \%$ of all energy in the United States, this represents significant potential energy savings.

The remainder of the paper is organized as follows. Section I describes the BVR management data as well as the non-public CM data. Section II gives the methodology and the results. Section III provides a discussion of the findings and section IV concludes.

\footnotetext{
${ }^{8}$ As detailed later in the paper, this is for a typical firm in an industry whose average energy intensity (energy expenditure/gross output) is .05 .
} 


\section{Data}

The two sources of data used in this paper are the Bloom and Van Reenen management survey data and the non-public U.S. Census of Manufactures. The management data were constructed through the use of a survey tool created by Bloom, Van Reenen and a large, global consulting firm. The process of collecting the data relied on a unique survey methodology designed first to obtain interviews from plant managers and then to elicit accurate responses regarding their management techniques. After a number of rounds of testing and development, the surveys were administered by MBA students at the London School of Economics in 2006 and 2007. Over 4,000 firms were interviewed in 12 countries around the world. ${ }^{9}$ More surveys have been conducted since the data we use became available.

While firms from all over the world were interviewed, this project uses only data collected on U.S. firms. Medium size U.S. manufacturing firms were randomly selected from Compustat database to participate. Once selected, interviewers conducted hour long interviews with plant managers. Plant managers were chosen as the subjects of the interview so as to obtain answers from an individual in the firm who would have intimate knowledge of the plant's floor level operations as well as knowledge of senior management at company headquarters. The interviews were framed to the plant managers as being a "piece of work" which sought to study the workings of a plant. ${ }^{10}$ The survey was "double-blind" in that the plant managers were unaware they were being scored and the interviewers had no prior knowledge of the company's

\footnotetext{
${ }^{9}$ Additional survey data has been collected in recent years as part of the World Management Survey.

${ }^{10}$ Interviewers were given incentives based on the response rate percentage they were able to obtain. The final response rate was 54 percent.
} 
performance. The plant managers were asked open-ended questions on 18 management practices which are grouped into four areas: operations, monitoring, incentives and targets. The operations category asks questions on the production process and the adoption of lean manufacturing techniques. The monitoring category asks questions on the types of production and input data that is collected as well as how the performance of capital and workers is measured. The incentives category asks questions on the hiring and firing of workers as well as the criteria for bonuses and promotions. Finally the targets category asks whether the firm has targets, how they are implemented, whether they are demanding and if there are consequences for consistently failing to meet them.

The interviewer scored each of the 18 management practices on a scale from 1 to 5 with 5 indicating the best possible management in that category. A number of checks were put in place to ensure consistent scoring by the interviewers. First, a common scoring guide was given to the interviewers to provide examples of typical answers and how each one should. A number of interviews were conducted with multiple people listening and independently scoring the answers of the plant managers. Firms with multiple establishments were frequently the subject of multiple interviews to ensure that management scores were correlated across a firm's different plants. Bloom and Van Reenen (2007) show that the scores are robust to these and other consistency checks. Furthermore, because interviewers surveyed on average 50 firms, the regressions can use interviewer fixed effects to control for any systemic differences between the interviewers. Additional data was collected on the day of the week the interview took place, the length of the interview, the gender of the plant manager and the plant manager's tenure at the firm. These interview variables are defined as noise controls in the regressions and are included to control for any bias associated with the scoring process itself. 
The overall management score was created by simply taking the average of the 18 management practice scores. Four management component scores were created as well, representing the average of the questions in the operations, monitoring, incentives and targets categories. Appendix A shows these categories, the questions asked, possible responses and how these responses would be scored in more detail.

The firm level survey data was then matched in to the $2007 \mathrm{CM}$ which contains detailed plant level data for all manufactures in the United States. Crucially, the CM contains the total value of shipments, detailed employment data, the value of the capital stock, value of intermediate expenditures and total energy expenditure. A common firm identifier in the $\mathrm{CM}$ allows us to link establishments in a firm and assign them a common management score. However, linking the firm level BVR survey data into the CM required matching by company name and address. Overall we successfully matched 321 of the 598 firms in the U.S. subset of the BVR management survey. Some basic summary statistics on the matched and unmatched firms are provided in Table 1. See the data appendix for more information on the matching and data cleaning process.

\section{Methodology and Results}

To analyze the relationship between management practices and energy use, we develop a two step procedure which first creates a straightforward measure of the energy efficiency for each plant in the $\mathrm{CM}$ and then regresses that measure on management practice variables for those plants matched from the BVR data. Our approach differs from previous methods in three fundamental ways; greater use of industry detail, controls for intermediate inputs, and use of 
relative energy intensity of industries. We also present results obtained using the Bloom et al. (2010) methodology.

The first important feature of the model is its use of detailed industry information. Different industries require widely varying amounts of energy depending on the product they are producing. The three digit industry code fixed effects used in previous research account for some of these differences but even within three digit industries there is a wide variety of products that are produced and a wide variety of ways methods which can be used to produce them. The Bloom et al. (2010) specification creates an energy efficiency measure based only on data for those establishments whose parent firms are found in the management survey. A significantly more industry specific measure of energy efficiency would take advantage of the entirety of the data available to us through the $\mathrm{CM}$ and would compare the plants not only to those in the management survey but to every manufacturing establishment in the entire United States. For example, at the three digit level a low energy intensity pharmaceutical manufacturer would be lumped together with a very energy intensive manufacturer of ethylene. Using the data on all plants will allow for the use of 6-digit NAICS industry controls and will significantly improve the specificity of the energy efficiency measure.

A second important aspect of the specification is its ability to control for the amount of intermediate inputs used by the establishment. The amount of intermediate inputs required in the production process can be a major determinant of the amount of energy used by an establishment. Two plants that produce the exact same amount of output may have very different energy requirements if one of them processes the raw materials themselves, while the other uses 
intermediate inputs purchased and produced by a separate establishment. ${ }^{11}$ Boyd, G., T. Kuzmenko, et al. (2011) provide some statistical evidence of this.

A final feature of the model allows for management practices to have heterogeneous impacts on energy efficiency based on the type of product being produced. The model specification allows for a test of whether the effects of management practices will be most likely to spillover into energy efficiency if energy is a significant portion of the firm's input costs. Past research has made no attempt to differentiate management's impact by industry. ${ }^{12}$ If management practices are driving energy efficiency then the relationship may be more evident in industries for which energy is a significant cost. Creating a specification which demonstrates differential impacts by industry would bolster the results.

We develop a two-step procedure which first creates a straightforward measure of energy efficiency based on data from the entire $\mathrm{CM}$, and then regress that measure on management practices and the survey control variables. Consider the following first stage specification which is run separately for each of the 450 6-digit NAICS manufacturing industries:

$$
e e_{i}=\beta_{0}+\beta_{v a} v a_{i}+\varepsilon_{i}
$$

Here, $e e_{i}$ is the logged energy expenditure of establishment $i$ and $v a_{i}$ is that establishment's logged value added (gross output - non-energy intermediate inputs). In this specification the residual, $\varepsilon_{i}$, represents the percent difference from the mean conditional on the establishment's value added. By defining $\varepsilon_{i}$ as the establishment's relative energy intensity we obtain a measure

\footnotetext{
${ }^{11}$ This is partially controlled for in the specifications which include the value of the capital stock, but a better control would account for the value of intermediate inputs into the equation.

${ }^{12}$ Results in past research may be being driven by the high energy industries but the model specification gives no way to examine this.
} 
of each establishment's relative energy performance which addresses the first two concerns above. ${ }^{13}$ In this specification, establishments are compared to others in their narrowly defined industry ensuring that a low energy cosmetics manufacturer is no longer lumped together with a very energy intensive manufacturer of ethylene. Second, energy intensity is allowed to vary by the amount of value added within the more narrowly defined industry. Establishments that purchase more preprocessed inputs will have lower value added compared to those that purchase raw materials and produced the intermediate goods internally. This should be reflected in their energy intensity measure, for example a plastics plant that purchases ethylene would have lower energy use than one that produces the ethylene internally.

The second step of the procedure, shown below in equation 2 defines $\varepsilon_{i}$ (the residual from equation (1) as EnergyInt $t_{i}$ and regresses this energy intensity variable on the management score $M$, and other firm and survey controls, represented by $\mathrm{X}$, that are found only in the matched sub-sample of the CM with the management data.

$$
\text { EnergyInt }_{i}=\delta_{0}+\beta_{M} M_{i}+X_{i}+\epsilon_{i}
$$

The results from equation (2) are found in Table 2. As with the original specification, a negative coefficient on the management score would imply that good management practices are associated with energy efficiency. Contrary to Bloom et al, the average management score is shown to have no clear relationship with a firm's energy efficiency. The coefficients point in the expected direction but lack statistical significance. Table 3 separates out the targets component

\footnotetext{
${ }^{13}$ State dummies are also included in equation 1 to account for differences in energy prices across regions. The ranking of establishments based on their residual is very similar when combinations of gross output, capital and labor are included on the right-hand side. Simply including value added appears to do a good job of controlling input mixture. Scale effects are mitigated by the use of logged energy expenditure.
} 
from the operations, monitoring and incentives components to determine whether specific aspects of good management have differential impacts on energy. However, the two-step procedure does not immediately reveal any relationship between practices and energy inefficiency. Column 3, which shows the most detailed specification, continues to find a negative but statistically insignificant relationship between energy use and the components of management.

These results, while of interest, continue to make no distinction between industries which require little energy in their production process and those whose production process requires a significant quantity. As seen in Figure 1, the share of energy costs is quite low for the large majority of industries. One hypothesis is that management practices are more likely to translate into lower energy use in those industries where energy is a higher portion of their costs. To examine this, we interact the management variable (and its components) with the energy intensity of the entire 6-digit NAICS industry to which the plant belongs. Consider equation (3) below

$$
\text { EnergyInt }_{i}=\delta_{0}+\beta_{M \times I N T} M_{i} \times \operatorname{Int}_{k}+\beta_{M} M_{i}+\beta_{I N T} \operatorname{Int}_{k}+X_{i}+\epsilon_{i}
$$

The specification follows equation 2 but includes an industry energy intensity variable, $\operatorname{Int}_{k}$, as well as the interaction of this variable with the management score. ${ }^{14}$ Int $_{k}$ is defined as the energy expenditure of all establishments in the industry divided by the overall output of that industry. ${ }^{15}$ The coefficient $\beta_{M \times I N T}$ provides a measure of whether management impacts energy efficiency

\footnotetext{
${ }^{14}$ Other specifications not reported here have interacted the management variable with an indicator variable equal to one if the establishment is in an industry with an energy intensity measure greater than .05. Given disclosure requirements, we only release one sample of establishments. Regressions run on subsamples (for example, only on plants in energy intensive industries) present a disclosure risk to Census.$$
{ }^{15} \text { Int }_{k}={ }_{i=1}^{n} E E_{i} / \quad{ }_{i=1}^{n} G O_{i} \forall i \in k \text {. }
$$ 
more for firms in high energy industries. Panel 1 of Table 4 presents the results for Equation 3 and shows the coefficient $\beta_{M \times I N T}$ to be negative and marginally significant. Using the coefficient of -.385 found in Column 3 of Panel 1 this implies that, for a firm in a high energy industry (with $\left.I n t_{k}=.05\right)$ an increase in the management score from the $25^{\text {th }}$ to the $75^{\text {th }}$ percentile would result in a reduction in energy expenditure of 1.5 percent. $^{16}$

Panel 2 again separates the people and operations components from targets in the management score and interacts each with the industry energy intensity variable. This is analogous to separating the management score as done in Table 2. The results, found in Panel 2 of Table 4 show that most forms of good management lead to significant improvements in energy efficiency for firms in high energy industries. However, the targets component is shown to have the opposite effect. Conditional on other management practices, when a firm implements strong targets we find this to have a negative impact on energy efficiency, particularly within industries for which energy is a substantial portion of their overall costs. As the coefficients show in table 4, Targets, as well as other management practices, are shown to have little distinguishable impact on energy efficiency for firms in low energy industries. If we consider a firm in a high energy industry, moving from the $25^{\text {th }}$ percentile to the $75^{\text {th }}$ percentile of targets management is shown to increase energy expenditure by $13 \%$, conditional on other firm management practices and firm characteristics. On the other hand, moving from the $25^{\text {th }}$ to the $75^{\text {th }}$ percentiles of all other management practices is shown to reduce energy consumption by $15 \%$.

\footnotetext{
${ }^{16}$ The predicted change in Energy Int $t_{i}$ when moving from $25^{\text {th }}$ management percentile (score of 2.889 ) to $75^{\text {th }}$

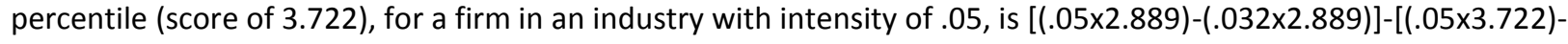
$(.032 \times 3.722)]=.015$
} 
As a comparison to our approach, we run the following econometric specification proposed by Bloom et al. (2010)

$$
(E E / G O)_{i} \times 100=\alpha_{g o} g o_{i}+\alpha_{l} l_{i}+\alpha_{k} k_{i}+\beta M_{i}+\gamma Z_{i}+u_{i}
$$

Where $E E$ is the total energy expended for establishment $i, G O$ is the gross output and $g o, l$, and $k$ are the logged values of gross output, number of workers and value of capital respectively. Gross output, labor and capital are included to account for potential economies of scale in energy use as well as input mixture. The key coefficient of interest is $\beta$, which represents the relationship between the management score and energy expended per dollar of gross output. The vector $Z$ is a broad set of controls which includes a full set of 3-digit NAICS fixed effects, various firm characteristics such as firm age and ownership structure, as well as the survey noise controls, such as interviewer fixed effects, that were described in the data section.

The findings for this specification are reported in Table 5. Given the definition of the energy intensity variable, a negative management coefficient would imply that an increase in management quality leads to a decrease in energy use. Column 1 is the most basic specification and simply regresses energy intensity on the management coefficient and a full set of 3-digit industry code fixed effects. Column 2 additionally controls for firm age, which, among other things, may partially control for the vintage of the capital stock. Column 3 adds in region and survey noise controls as well as gross output in order to control for energy economies of scale. Column 4 additionally includes the logged value of capital and labor as additional controls for scale as well as input mixture. 
The results found in Table 5 represent a departure from Bloom et al. (2010), but are consistent with our results. Columns 1-3 show a coefficient on the management variable very close to zero. The coefficient in column 4 is negative and closer to the results found for UK plants but is not statistically significant. At best, these findings show a modest relationship between energy efficiency and management, but very little can be determined given the size of the standard errors. These findings are in contrast with the UK results which show a robust significant relationship between management and energy efficiency for all of these specifications and a similar sample size.

As done above, we split the management score into its four major components (Operations, Monitoring, Incentives and Targets) as originally defined in Bloom (2007). Columns 5-8 of Table 2 run separate regressions for each of the four management components. While not always statistically significant, the Operations, Monitoring and Incentives components are all shown to predict energy efficiency. The coefficient on the targets component is shown to be very close to zero. This is surprising given the strong correlation of the targets component with all other management components. ${ }^{17}$

Seeking to examine this relationship further, Table 6 presents identical regressions as found in columns 1-4 of Table 5 but separates out the targets component from the overall management score and includes both these variables in the regression. Controlling for targets, the remaining management score component is shown to strongly predict energy efficiency and the results are quite similar to the findings found in previous research on UK plants (Bloom et al.

\footnotetext{
${ }^{17}$ The correlation between targets and all other management components is 69
} 
2010, Martin et al. 2012). The coefficient on targets is positive, implying energy inefficiency and is statistically significant in two of the specifications, but not the most detailed.

Of course, these findings do not necessarily imply a causal relationship between management and energy efficiency, but do suggest the nature of possible spillover effects. It is possible for example that firms who are likely to hire management consultants may also be more likely to adopt energy saving technology. Given the nature of the data, the causality concern requires resources beyond our current grasp and that we cannot directly address, rather we argue that the various correlations (or lack thereof) between management practices and energy use for U.S. plants is an interesting finding on its own that is suggestive of positive spillovers in some cases and an "energy management gap," particularly regarding targets. ${ }^{18}$ The two major findings we take from the empirical analysis are 1) "good" management practices most strongly predict energy savings within industries that require significant energy in their production process and 2) the targets component of the management score appears to be associated with high energy usage, after controlling for other management practices. Both of these findings warrant further discussion as to their place in literature as well as their overall credibility.

Past research on UK plants has shown a clear relationship between the overall management score and energy efficiency and has made no direct attempt to determine which industries were driving the observed efficiency gains associated with good management practices. As shown in Table 4, we demonstrate that in the U.S. the spillover to energy savings from management occur predominantly in the more energy intensive industries. This result has

\footnotetext{
${ }^{18}$ Currently research is being performed to address this concern. Firms are being re-interviewed to obtain panel data on the management variable and randomized control trials are being run in developing countries (Bloom 2012).
} 
two important implications. First, that these savings occur in high energy industries implies a far greater overall drop in energy quantity consumed than had previously been estimated. Had the relative energy efficiency gains only occurred in low energy industries, then the overall quantity of energy use reduction would be significantly less. ${ }^{19}$ The second implication is that the driving mechanism through which management reduces energy consumption is likely to be through increased profits rather than a correlation with altruism. Firms whose production process requires little energy costs, stand to gain relatively little from a one percent decrease in their energy consumption. However, for firms in energy intensive industries, a one percent decrease will have a sizable impact on their profit level. If a correlation with altruism were driving the result, we would expect to see improvements in energy efficiency for firms in all industries, and not only those for whom energy expenditure has a large impact on their profits. This is also consistent with the notion that energy is more likely to be on the "management radar" when it is a higher share of costs, hence more spillover from general management practices to energy.

The other major finding of this paper is that high scores on the Targets component of management practices, conditional on the other management components, appears to cause firms to be inefficient in their use of energy. While initially surprising, we believe that this result has support from the economics and management literature on goal and target setting as well as anecdotal support from industry insiders. To begin with, it is useful to revisit the specific targets questions which were asked of the plant managers. Of the 18 management practices, five of them were part of the targets component. These five sought to measure the type of targets, whether the

\footnotetext{
${ }^{19}$ For example, the estimated energy reduction accounted for by good management in Bloom et al (2010) is assumed to occur for a firm whose energy intensity measure at the average of all industries. We have shown that, while little energy will be saved for a firm in the average industry, good management implies significant energy savings for firms in the most energy intensive industries.
} 
targets were interconnected, the time horizon of the targets, whether or not the goals were stretching, and the clarity of the goals. There is no language in the questions that refer specifically to energy targets and according to the guide provided to the interviewers, high scores were to be given for well-developed financial and production targets that pushed plants and their managers to achieve a high level of output by a certain deadline. Firms were also given high scores if these goals were clear and all employees were actively striving to meet them.

The implications of goal setting and targets in the form of agency contract have been examined in depth within both the personnel economics and management literature (see Prendergrast (1999) for a review). Among the key findings is that setting specific targets on certain outcomes, particularly if tied to compensation can frequently lead to other often important outcomes being ignored. This includes the possibility that agents (e.g. plant managers) will respond to the target objective in such a way that is actually harmful to the firm. If firms set strict production targets and there is significant pressure on plants to meet them, then other outcomes, such as the efficient use of energy may be ignored. For example, plants operating under real time electricity pricing may be forced to ramp up production when electricity prices are high and delay maintenance / upgrades of energy using capital in order to meet production quotas.

Not only does the economics literature provide a plausible explanation for the result on targets, but there is also substantial anecdotal evidence from plant managers suggesting energy efficiency is frequently ignored when production targets are pressing. Since the questionnaire never mentions energy and it is possible that the business targets being used cause the plant to use more energy. For example, concerns over product quality delayed the implementation of 
some very simple energy efficiency activities in auto assembly paint booths at Toyota for as many as 5 years. After addressing this long list of concerns, the efficiency measures were finally implemented. No quality issues emerged and the changes resulted in substantial energy savings $^{20}$. If "production is king" and targets do not include energy but are primarily to meet production, sales, or quality goals, then there may be no "room at the table" for energy efficiency activities, even if these activity are unlikely to impede those goals. This failure to prioritize energy is supported with some anecdotal evidence as described by three corporate energy managers from a range of companies. ${ }^{21}$ Thomas Pagliuco, corporate energy manager at Merck, characterizes the prioritization this way:

For most plants, the priorities are: safety, quality, output, compliance, and cost, and cost is probably prioritized as labor, raw material, maintenance/materials, and energy. My experience, even for a large energy user, is that energy is at best a 6th or 7th priority.

Eric Battino, Corporate Energy Manager at Pepsi goes on to say:

Targets are not enough. In fact targets, if they are not tied to fiscal accountability, are generally meaningless to operations.

However, the importance of employee engagement and operations, relative to targets is also born out anecdotally. Thomas Pagliuco, corporate energy manager at Merck, put it this way.

People and operations will help drive energy efficiency as this forms the base for a more efficient overall operation and achievement of the targets. People and processes are the base; targets change. Good people and processes will allow the company to meet their targets, it doesn't work the other way.

Sharon Nolen Eastman Chemical

I think you can more easily make progress with good people and good operations and less easily with a target alone.

\footnotetext{
${ }^{20}$ Brad Reed, 2003, presentation to the $3^{\text {rd }}$ Annual Energy Star Focus for Motor Vehicle Assembly, Detroit, MI.

${ }^{21}$ Private communications from Thomas Pagliuco, Eric Battino, and Sharon Nolen.
} 
In addition, as discussed in (Worrell 2011) ten Canadian potash operations published the details of their benchmarking exercise (CFI 2003) which showed that increased employee awareness and training was the most frequently identified opportunity for improved energy performance.

\section{Conclusion}

The results found in this paper enhance the understanding of the relationship between energy efficiency and management in a variety of ways. First, we find that for firms in the United States, this relationship is more nuanced than has been shown for firms in the UK. While most "good" management practices have beneficial spillovers on energy efficiency, an emphasis on targets, particularly if they are non-energy targets, is correlated with energy inefficiency. Additionally, using a more precise measure of energy efficiency we show that the energy gains associated with good management occur primarily in energy intensive industries. Therefore the overall energy gains associated with good management are larger than previous estimates which assumed the savings occurred for the average industry.

Further research is warranted to more closely examine the relationships at hand in this paper and the implications of the energy management gap. Panel data and randomized experiments would present a more causal interpretation. More work should also be done to determine the types of targets employed by a firm and the spillovers these targets can have on a variety outcomes especially for outcomes like energy efficiency which create negative externalities. 


\section{References}

Bloom, N., and J. Van Reenen (2007), "Measuring and explaining management practices across firms and countries", Quarterly Journal of Economics, CXXII: 1341-1408.

Bloom, N., and J. Van Reenen (2009), "The economics of management practices", Journal of Economic Perspectives.

Boyd, G., E. Dutrow, et al. (2008). "The Evolution of the Energy Star Industrial Energy Performance Indicator for Benchmarking Plant Level Manufacturing Energy Use." Journal of Cleaner Production. Volume 16(Issue 6): 709-715.

Boyd, G., T. Kuzmenko, et al. (2011). Preliminary Analysis Of The Distributions Of Carbon And Energy Intensity For 27 Energy Intensive Trade Exposed Industrial Sectors. Duke Environmental Economics Working Paper Series WP-EE-11-03, Nicholas Institute for Environmental Policy Solutions.

CFI (2003) Energy benchmarking: Canadian potash production facilities. Canadian Fertilizer Institute, Ottawa, Canada, Canadian Industry Program for Energy Conservation.

DeCanio, S. and Watkins, W. (1998), "Investment in energy efficiency: do the characteristics of firms matter?", Review of Economics and Statistics, 80(1): 95-107.

DeCanio, S. (1993), "Barriers within firms to energy efficient investments", Energy Policy, 21: 906-914.

Farrell, M. J. (1957). "The Measurement of Productive Efficiency." Journal of the Royal Statistical Society. Series A (General) 120(3): 253-290.

Howarth, R., Haddad, B. and Paton, B. (2000), "The economics of energy efficiency: insights from voluntary participation programs", Energy Policy, 28: 477-486.

Ichniowski, C., K. Shaw and G. Prenushi (1997), "The Effects of Human Resource Management: A Study of Steel Finishing Lines”, American Economic Review, LXXXVII (3): 291-313.

Jaffe, Adam B. and R. N. Stavins. "Energy-Efficiency Investments and Public-Policy." The Energy Journal 15. 2 (1994): 43-65.

Jaffe, Adam B. and R. N. Stavins. "The Energy Efficiency Gap: What Does It Mean. Energy Policy 22. 10 (1994): 804-810.

Lazear, Edward P. "Speeding, Terrorism, and Teaching to the Test" Quarterly Journal of Economics. 
Lazear, Edward P and Paul Oyer. "Personnel Economics" published in Handbook of Organizational Economics. Eds Gibbons, R. and Roberts, J (2012)

McKinsey \& Co. 2009. "Unlocking Energy Efficiency in the U.S. Economy." http://www.mckinsey.com/clientservice/electricpowernaturalgas/downloads/US_energy_ efficiency_full_report.pdf.

Prendergrast, Canice. "The Provision of Incentives in Firms." Journal of Economic Literature. 37. 1 pp 7-63. (1999)

Price, L., E. Worrell, et al. (2003). Voluntary agreements for increasing energy-efficiency in industry: case study of a pilot project with the steel industry in Shandong Province, China. Industrial Summer Study on Energy Efficiency in Industry, Rye Brook, NY, ACEEE

Storey, M., G. Boyd, and J. Dowd, "Voluntary Agreements with Industry," in The Economics and Law of Voluntary Approaches, special issue of Fondazione Eri Enrico Mathei, Series 26.97 (Feb. 1997).

Syverson, C. (2011). "What Determines Productivity?" Journal of Economic Literature 49(2): 326-365.

Worrell, Ernst. The Next Frontier to Realize Industrial Energy Efficiency. Proc. World Renewable Energy Congress 2011, Linköping, Sweden, May 8-13th, 2011 


\section{Data Appendix}

The BVR management survey interviews plant managers with intimate knowledge of both the floor level production process as well as the decisions made by the firm's upper level management. These scores are intended to be firm level scores which apply to all establishments within the firm. It is possible that this may result in an imprecise measure of firm management if there is heterogeneity in management practices across a firm's establishments. However, we follow the lead of BVR and apply the score to each establishment owned by the firm. We apply two techniques to move from the establishment to the firm level. The first is to simply aggregate the labor, capital, intermediate inputs and energy for every establishment within a firm and use these aggregate measures to run firm level regressions. This provides firm level data that is comparable to the Compustat firm level data used in Bloom and Van Reenen (2007). Our preferred method uses establishment level data found in the CM and assigns each establishment the management score of the firm. We weight each establishment according to its percentage of the firm's total sales. This weighting is performed to ensure that one or two firms with dozens of establishments are not dominating the results. Using the establishment level data allows for the use of more precise industry codes and input information, both of which will be crucial for our measurement of energy efficiency.

Matching the BVR data to the 2007 Census of Manufactures is a two step process relying on name, address and industry variables. First the BVR data is merged to Census' Business Register, which unlike the Census of Manufactures, contains the establishment name. After matching to the Business Register we use a common establishment id (survuid) to merge in the establishment level CM data. The Firm ID of the establishment is then used to locate other establishments owned by the firm. We drop establishments whose energy efficiency variable (EE/GO) falls in the top and bottom percentile of the matched sample. This removes observations which suffer from misreporting. After the cleaning has been performed the final matched data set contains 321 firms and 4242 establishments for a match rate of approximately $54 \%$. The CM is performed in years ending in 2 and 7. For the years in between, the Census performs the Annual Survey of Manufactures on roughly $16 \%$ of all manufacturing establishments in the CM. We attempted to match the management survey data to the ASM years as well but our match rate was very low. We also considered using data from the $2002 \mathrm{CM}$. However, we decide against using this data because nearly half of firms report changing ownership or making major management practice changes in the 3 years prior to the survey. 
Table 1: Summary Statistics

\begin{tabular}{|l|c|c|c|c|c|c|c|c|}
\hline & \multicolumn{2}{|c|}{ Management } & \multicolumn{2}{c|}{$\begin{array}{c}\text { Monitoring/ } \\
\text { Incentive/Operations }\end{array}$} & \multicolumn{2}{c|}{ Targets } & \multicolumn{2}{c|}{ Firm Age } \\
\hline & Mean & S.D. & Mean & S.D. & Mean & S.D. & Mean & S.D. \\
\hline $\begin{array}{l}\text { Full } \\
\text { Sample }\end{array}$ & 3.30 & .660 & 3.37 & .663 & 3.21 & .804 & 49.83 & 43.10 \\
\hline $\begin{array}{l}\text { Matched } \\
\text { Sample }\end{array}$ & 3.40 & .635 & 3.41 & .652 & 3.38 & .734 & 54.64 & 41.99 \\
\hline
\end{tabular}

Table 2: Energy Efficiency Results using full CM, 2-step process (Equation 1 used to generate the dependent variable, the results below come from estimating equation 2)

\begin{tabular}{|c|c|c|c|}
\hline VARIABLES & $\begin{array}{c}1 \\
\text { EnergyInt }\end{array}$ & $\begin{array}{c}2 \\
\text { EnergyInt }\end{array}$ & $\begin{array}{c}3 \\
\text { EnergyInt }\end{array}$ \\
\hline \multicolumn{4}{|c|}{ Panel 1} \\
\hline Management & $\begin{array}{l}.0021 \\
(.042)\end{array}$ & $\begin{array}{l}-.033 \\
(.046)\end{array}$ & $\begin{array}{c}-.037 \\
(0.047)\end{array}$ \\
\hline \multicolumn{4}{|c|}{ Panel 2} \\
\hline Ops/Mon/Incent & $\begin{array}{l}.002 \\
.059)\end{array}$ & $\begin{array}{l}-.033 \\
(.060)\end{array}$ & $\begin{array}{l}.054 \\
(.061)\end{array}$ \\
\hline Targets & $\begin{array}{c}.003 \\
(.055)\end{array}$ & $\begin{array}{l}-.001 \\
(.056)\end{array}$ & $\begin{array}{c}.014 \\
(.056)\end{array}$ \\
\hline State Dummies & Yes & Yes & Yes \\
\hline Firm Age & & Yes & Yes \\
\hline Noise Controls & & Yes & Yes \\
\hline Firm Controls & & & Yes \\
\hline
\end{tabular}

Standard Errors are Robust to heteroskedasticity. 
Table 3: Energy Efficiency Results using full CM, 2-step process

\begin{tabular}{|c|c|c|c|}
\hline VARIABLES & $\begin{array}{c}1 \\
\text { En_Eff }\end{array}$ & $\begin{array}{c}2 \\
\text { En_Eff }\end{array}$ & ${ }^{3} n^{3} \_$Eff \\
\hline MGMTxInd_Int & $\begin{array}{l}-.332 \\
(.227)\end{array}$ & $\begin{array}{l}-.425^{*} \\
(.234)\end{array}$ & $\begin{array}{c}-.385 \\
(0.239)\end{array}$ \\
\hline MGMT & $\begin{array}{c}.006 \\
(.042)\end{array}$ & $\begin{array}{c}.027 \\
(.046)\end{array}$ & $\begin{array}{l}-.032 \\
(.047)\end{array}$ \\
\hline $\begin{array}{l}\text { State Dummies } \\
\text { Firm Age } \\
\text { Noise Controls } \\
\text { Firm Controls }\end{array}$ & Yes & $\begin{array}{l}\text { Yes } \\
\text { Yes } \\
\text { Yes }\end{array}$ & $\begin{array}{l}\text { Yes } \\
\text { Yes } \\
\text { Yes } \\
\text { Yes }\end{array}$ \\
\hline $\begin{array}{l}\text { Firms } \\
\text { R-squared }\end{array}$ & $\begin{array}{c}321 \\
0.104\end{array}$ & $\begin{array}{c}321 \\
0.138\end{array}$ & $\begin{array}{c}321 \\
0.141\end{array}$ \\
\hline
\end{tabular}


Table 4: Energy Efficiency Results using full CM, 2-step process

\begin{tabular}{|c|c|c|c|}
\hline VARIABLES & $\begin{array}{c}1 \\
\text { EnergyInt } \\
\end{array}$ & $\begin{array}{c}2 \\
\text { EnergyInt } \\
\end{array}$ & $\begin{array}{c}3 \\
\text { EnergyInt } \\
\end{array}$ \\
\hline \multicolumn{4}{|c|}{ Panel 1} \\
\hline MGMT x Ind_Int & $\begin{array}{l}-.332 \\
(.227)\end{array}$ & $\begin{array}{l}-.425^{*} \\
(.234)\end{array}$ & $\begin{array}{c}-.385 \\
(0.239)\end{array}$ \\
\hline MGMT & $\begin{array}{c}.006 \\
(.042) \\
\end{array}$ & $\begin{array}{c}.027 \\
(.046) \\
\end{array}$ & $\begin{array}{l}-.032 \\
(.047) \\
\end{array}$ \\
\hline \multicolumn{4}{|c|}{ Panel 2} \\
\hline Ops/Mon/Incent x Ind_Int & $\begin{array}{l}-3.37 * \\
(1.74)\end{array}$ & $\begin{array}{c}-3.85 * * \\
(1.80)\end{array}$ & $\begin{array}{c}-3.59 * * \\
(1.75)\end{array}$ \\
\hline Targets $x$ Ind_Int & $\begin{array}{l}2.99 * \\
(1.64)\end{array}$ & $\begin{array}{c}3.37 * * \\
(1.68)\end{array}$ & $\begin{array}{l}3.14 * \\
(1.64)\end{array}$ \\
\hline Ops/Mon/Incent & $\begin{array}{c}.066 \\
(.072)\end{array}$ & $\begin{array}{c}.042 \\
(.073)\end{array}$ & $\begin{array}{l}.020 \\
(.073)\end{array}$ \\
\hline Targets & $\begin{array}{l}-.060 \\
(.068) \\
\end{array}$ & $\begin{array}{l}-.072 \\
(.073) \\
\end{array}$ & $\begin{array}{l}-.056 \\
(.071) \\
\end{array}$ \\
\hline State Dummies & Yes & Yes & Yes \\
\hline Firm Age & & Yes & Yes \\
\hline Noise Controls & & Yes & Yes \\
\hline Firm Controls & & & Yes \\
\hline Firms & 321 & 321 & 321 \\
\hline
\end{tabular}

Standard Errors are Robust to heteroskedasticity. 
Table 5: Regression Results using one step process (See Equation 1)

\begin{tabular}{|c|c|c|c|c|c|c|c|c|}
\hline VARIABLES & $\begin{array}{c}1 \\
\text { EE/GOx100 } \\
\end{array}$ & $\begin{array}{c}2 \\
\text { EE/GOx100 } \\
\end{array}$ & $\begin{array}{c}3 \\
\text { EE/GOx100 } \\
\end{array}$ & $\begin{array}{c}4 \\
\text { EE/GOx100 } \\
\end{array}$ & $\begin{array}{c}5 \\
\text { EE/GOx100 } \\
\end{array}$ & $\begin{array}{c}6 \\
\text { EE/GOx100 } \\
\end{array}$ & $\begin{array}{c}7 \\
\text { EE/GOx100 } \\
\end{array}$ & $\begin{array}{c}8 \\
\text { EE/GOx100 } \\
\end{array}$ \\
\hline Management & $\begin{array}{l}.0014 \\
(.122)\end{array}$ & $\begin{array}{l}-.030 \\
(.187)\end{array}$ & $\begin{array}{c}-.031 \\
(0.218)\end{array}$ & $\begin{array}{c}-.169 \\
(0.149)\end{array}$ & & & & \\
\hline Operations & & & & & $\begin{array}{c}-.221 * * \\
(.097)\end{array}$ & & & \\
\hline Monitoring & & & & & & $\begin{array}{l}-.1135 \\
(.169)\end{array}$ & & \\
\hline Incentives & & & & & & & $\begin{array}{l}-.139 \\
(.154)\end{array}$ & \\
\hline Targets & & & & & & & & $\begin{array}{l}-.001 \\
(.153)\end{array}$ \\
\hline $\ln (\mathrm{go})$ & & & $\begin{array}{l}.0022 \\
(.130)\end{array}$ & $\begin{array}{c}-1.008 * * * \\
(.166)\end{array}$ & $\begin{array}{c}-1.056 * * * \\
(.183)\end{array}$ & $\begin{array}{c}-1.066 * * * \\
(.181)\end{array}$ & $\begin{array}{c}-1.062 * * * \\
(.180)\end{array}$ & $\begin{array}{c}-1.069 * * * \\
(.177)\end{array}$ \\
\hline $\ln$ (labor) & & & & $\begin{array}{l}-.203 \\
(.240)\end{array}$ & $\begin{array}{l}-.182 \\
(.230)\end{array}$ & $\begin{array}{l}-.166 \\
(.236)\end{array}$ & $\begin{array}{l}-.163 \\
(.240)\end{array}$ & $\begin{array}{l}-.162 \\
(.240)\end{array}$ \\
\hline $\ln$ (capital) & & & & $\begin{array}{c}1.252 * * * \\
(.313)\end{array}$ & $\begin{array}{c}1.238 * * * \\
(.303)\end{array}$ & $\begin{array}{c}1.222 * * * \\
(.304)\end{array}$ & $\begin{array}{c}1.214 * * * \\
(.302)\end{array}$ & $\begin{array}{c}1.214 * * * \\
(.306)\end{array}$ \\
\hline $\begin{array}{l}\text { NAICS } 3 \text { Controls } \\
\text { Firm Age } \\
\text { Noise Controls } \\
\text { Region Dummies }\end{array}$ & Yes & $\begin{array}{l}\text { Yes } \\
\text { Yes }\end{array}$ & $\begin{array}{l}\text { Yes } \\
\text { Yes } \\
\text { Yes } \\
\text { Yes }\end{array}$ & $\begin{array}{l}\text { Yes } \\
\text { Yes } \\
\text { Yes } \\
\text { Yes }\end{array}$ & $\begin{array}{l}\text { Yes } \\
\text { Yes } \\
\text { Yes } \\
\text { Yes }\end{array}$ & $\begin{array}{l}\text { Yes } \\
\text { Yes } \\
\text { Yes } \\
\text { Yes }\end{array}$ & $\begin{array}{l}\text { Yes } \\
\text { Yes } \\
\text { Yes } \\
\text { Yes }\end{array}$ & $\begin{array}{l}\text { Yes } \\
\text { Yes } \\
\text { Yes } \\
\text { Yes }\end{array}$ \\
\hline $\begin{array}{l}\text { Firms } \\
\text { R-squared }\end{array}$ & $\begin{array}{c}321 \\
0.263\end{array}$ & $\begin{array}{c}321 \\
0.301\end{array}$ & $\begin{array}{c}321 \\
0.303\end{array}$ & $\begin{array}{c}321 \\
0.385\end{array}$ & $\begin{array}{c}321 \\
0.386\end{array}$ & $\begin{array}{c}321 \\
0.385\end{array}$ & $\begin{array}{c}321 \\
0.385\end{array}$ & $\begin{array}{c}321 \\
0.384\end{array}$ \\
\hline
\end{tabular}


Table 6: Regression Results using one step process (Equation 1, separating Management into its components)

\begin{tabular}{|c|c|c|c|c|}
\hline VARIABLES & $\begin{array}{c}1 \\
\text { EE/GOx100 }\end{array}$ & $\begin{array}{c}2 \\
\mathrm{EE} / \mathrm{GO} \times 100\end{array}$ & $\begin{array}{c}3 \\
\text { EE/GOx100 }\end{array}$ & $\begin{array}{c}4 \\
\mathrm{EE} / \mathrm{GO} \times 100\end{array}$ \\
\hline Ops/Mon/Incent & $\begin{array}{l}-.223 \\
(.153)\end{array}$ & $\begin{array}{c}-.367 * * \\
(.161)\end{array}$ & $\begin{array}{c}-.367 * * \\
(0.163)\end{array}$ & $\begin{array}{c}-.456 * * * \\
(0.126)\end{array}$ \\
\hline Targets & $\begin{array}{l}.205 \\
(.166)\end{array}$ & $\begin{array}{l}.303 * * \\
(.126)\end{array}$ & $\begin{array}{l}.308 * * \\
(.145)\end{array}$ & $\begin{array}{l}.250 \\
(.152)\end{array}$ \\
\hline $\ln (\mathrm{go})$ & & & $\begin{array}{l}.0022 \\
(.130)\end{array}$ & $\begin{array}{c}-1.08 * * * \\
(.182)\end{array}$ \\
\hline $\ln$ (labor) & & & & $\begin{array}{l}-.161 \\
(.239)\end{array}$ \\
\hline $\ln$ (capital) & & & & $\begin{array}{c}1.222 * * * \\
(.306)\end{array}$ \\
\hline $\begin{array}{l}\text { NAICS } 3 \text { Controls } \\
\text { Firm Age } \\
\text { Noise Controls } \\
\text { Region Dummies }\end{array}$ & Yes & $\begin{array}{l}\text { Yes } \\
\text { Yes }\end{array}$ & $\begin{array}{l}\text { Yes } \\
\text { Yes } \\
\text { Yes } \\
\text { Yes }\end{array}$ & $\begin{array}{l}\text { Yes } \\
\text { Yes } \\
\text { Yes } \\
\text { Yes }\end{array}$ \\
\hline $\begin{array}{l}\text { Firms } \\
\text { R-squared }\end{array}$ & $\begin{array}{c}321 \\
0.263\end{array}$ & $\begin{array}{c}321 \\
0.301\end{array}$ & $\begin{array}{c}321 \\
0.303\end{array}$ & $\begin{array}{c}321 \\
0.355\end{array}$ \\
\hline
\end{tabular}


Figure 1: Energy Cost Share of Value Added (Less Energy) - 6-Digit NAICS

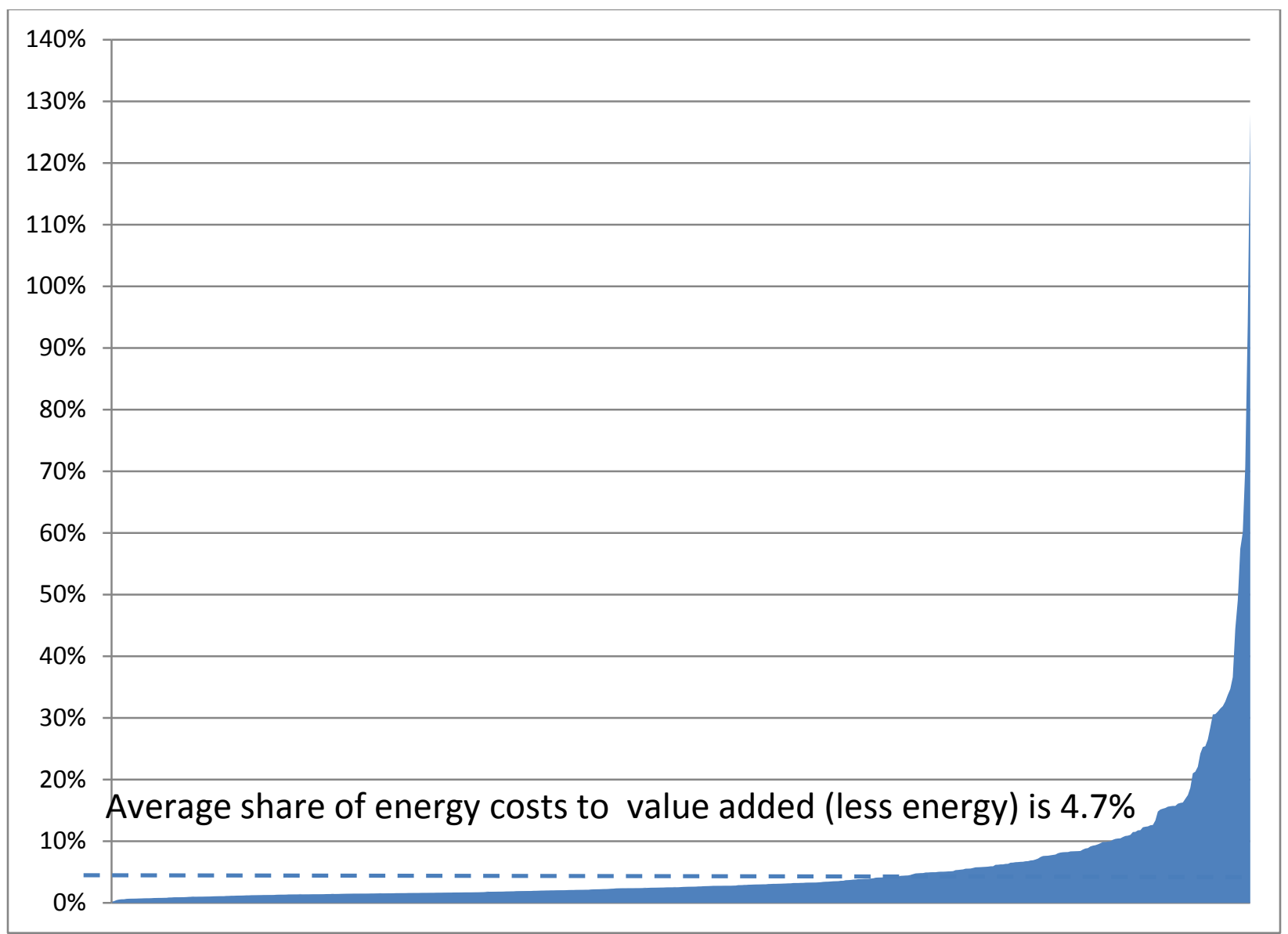

Source: 2007 Census of Manufacturing

(Note: This chart does not account for 14 (of 471) manufacturing sectors for which data on energy expenditures were withheld in the Economic Census to maintain confidentiality.) 


\section{Survey Appendix}

\begin{tabular}{|c|c|c|c|c|}
\hline Practice & $\begin{array}{l}\text { Practice } \\
\text { number }\end{array}$ & Practice type & & Example of questions we asked \\
\hline Modern manufacturing, introduction & 1 & Operations & $\begin{array}{l}\text { a) } \\
\text { b) } \\
\text { c) }\end{array}$ & $\begin{array}{l}\text { Can you describe the production process for me? } \\
\text { What kinds of lean (modern) manufacturing processes have } \\
\text { you introduced? Can you give me specific examples? } \\
\text { How do you manage inventory levels? What is done to } \\
\text { balance the line? }\end{array}$ \\
\hline Modern manufacturing, rationale & 2 & Operations & a) & $\begin{array}{l}\text { Can you take through the rationale to introduce these } \\
\text { processes? } \\
\text { What factors led to the adoption of these lean (modern) } \\
\text { management practices? }\end{array}$ \\
\hline Process documentation & 3 & Operations & $\begin{array}{l}\text { a) } \\
\text { b) } \\
\text { c) } \\
\text { d) }\end{array}$ & $\begin{array}{l}\text { How would you go about improving the manufacturing } \\
\text { process itself? } \\
\text { How do problems typically get exposed and fixed? } \\
\text { Talk me through the process for a recent problem. } \\
\text { Do the staff ever suggest process improvements? }\end{array}$ \\
\hline Performance tracking & 4 & Monitoring & $\begin{array}{l}\text { a) } \\
\text { b) } \\
\text { c) }\end{array}$ & $\begin{array}{l}\text { Tell me how you track production performance? } \\
\text { What kind of Key Performance Indicators (KPIs) would you use } \\
\text { for performance tracking? How frequently are these } \\
\text { measured? Who gets to see this KPI data? } \\
\text { If I were to walk through your factory could I tell how you } \\
\text { were doing against your KPI's? }\end{array}$ \\
\hline
\end{tabular}




\section{Performance review}

Performance dialogue

Consequence management

Target breadth

Target interconnection
Targets a) How do you review your Key Performance Indicators (KPIs)?

b) Tell me about a recent meeting. Who is involved in these meetings?

c) Who gets to see the results of this review?

a) How are these meetings structured? Tell me about your most recent meeting.

b) During these meeting, how much useful data do you have?

c) How useful do you find problem solving meetings?

d) What type of feedback occurs in these meetings?

a) What happens if there is a part of the business (or a manager) who isn't achieving agreed upon results? Can you give me a recent example?

b) What kind of consequences would follow such an action?

c) Are there are any parts of the business (or managers) that seem to repeatedly fail to carry out agreed actions?

a) What types of targets are set for the company? What are the goals for your plant?

b) Tell me about the financial and non-financial goals?

c) What do Company Head Quarters (CHQ) or their appropriate manager emphasize to you?

a) What is the motivation behind your goals?

b) How are these goals cascaded down to the individual workers?

c) What are the goals of the top management team (do they even know what they are!)?

d) How are your targets linked to company performance and their goals? 
Target time horizon

Targets are stretching

Performance clarity and comparability

Targets

Managing human capital

Rewarding high performance

Targets
How tough are your targets? Do you feel pushed by them?

b) On average, how often would you say that you meet your targets?

c) Are there any targets which are obviously too easy (will always be met) or too hard (will never be met)?

d) Do you feel that on targets that all groups receive the same degree of difficulty? Do some groups get easy targets?

a) What are your targets (i.e. do they know them exactly)? Tell me about them in full.

b) Does everyone know their targets? Does anyone complain that the targets are too complex?

c) How do people know about their own performance compared to other people's performance?

$13 \quad$ Incentives

a) Do senior managers discuss attracting and developing talented people?

b) Do senior managers get any rewards for bringing in and keeping talented people in the company?

c) Can you tell me about the talented people you have developed within your team? Did you get any rewards for this?

a) How does you appraisal system work? Tell me about the most recent round?

b) How does the bonus system work?

c) Are there any non-financial rewards for top-performers? 


\section{Removing poor performers}

Promoting high performers

Attracting human capital

Retaining human capital a) If you had a worker who could not do his job what would you do? Could you give me a recent example?

b) How long would underperformance be tolerated?

c) Do you find any workers who lead a sort of charmed life? Do some individuals always just manage to avoid being fixed/fired?

a) Can you rise up the company rapidly if you are really good? Are there any examples you can think of?

b) What about poor performers - do they get promoted more slowly? Are there any examples you can think of?

c) How would you identify and develop (i.e. train) your star performers?

d) If two people both joined the company 5 years ago and one was much better than the other would he/she be promoted faster?

a) What makes it distinctive to work at your company as opposed to your competitors?

b) If you were trying to sell your firm to me how would you do this (get them to try to do this)?

c) What don't people like about working in your firm?

a) If you had a star performer who wanted to leave what would the company do?

b) Could you give me an example of a star performers being persuaded to stay after wanting to leave?

c) Could you give me an example of a star performer who left the company without anyone trying to keep them? 